 \\ IJCTA Indonesian Journal of Tropical Aquatic
}

\section{The influence of different temperature against the rate of embryonic development and larval abnormality of Cantik Grouper (Epinephelus spp.)}

Aprisianus Julkarman Simbolon ${ }^{1, a}$, Ganjar Adhywirawan Sutarjo ${ }^{1, b, *}$, Hariyadi ${ }^{1, c}$

${ }^{1}$ Fisheries Department, Faculty of Agriculture and Animal Science, University of Muhammadiyah Malang, Indonesia.

aapri_julkarman@yahoo.co.id bganjar@umm.ac.id chariyadi@umm.ac.id

*Corresponding author

\section{ARTICLE INFO ABSTRACT}

\section{Keywords:}

Embryo development

Epinephelus sp.

Larval incubation

Temperature
Cantik grouper is the undue hybridization results grouper or cross-breeding between Epinephelus fuscoguttatus as a female and Epinephelus microdon as a male. The main barriers faced in the development of this commodity is still low levels of spawning up to seeding grouper. This study aimed to investigate optimum temperature observations against the rate of embryonic development Epinephelus sp. larvae. The fertilized eggs were incubated on 6 containers temperature treatment; each treatment there was repeated three times. The incubation temperature was kept on (A) $21-22{ }^{\circ} \mathrm{C}$; (B) $23-$ $24^{\circ} \mathrm{C}$; (C) $25-26^{\circ} \mathrm{C}$; (D) $27-28^{\circ} \mathrm{C}$; (E) $29-30^{\circ} \mathrm{C}$; (F) $31-32{ }^{\circ} \mathrm{C}$. Results showed that eggs were incubated at a temperature of $21-22^{\circ} \mathrm{C}$ embryonic development to a halt in the blastula, and temperature $23-24{ }^{\circ} \mathrm{C}$ stalled on phase myomere embryos. Temperature $25-26{ }^{\circ} \mathrm{C}$ needed $18 \mathrm{~h} 6 \mathrm{~min}$ by $8.33 \%$ abnormality rate. Temperature $27-28{ }^{\circ} \mathrm{C}$ needed $16 \mathrm{~h}$ to hatch with a degree of abnormality of $7.6 \%$. Temperature 29-30 ${ }^{\circ} \mathrm{C}$ needed $15 \mathrm{~h} 1 \mathrm{~min}$ for the hatch to the degree of abnormality of $5.33 \%$. The $31-32{ }^{\circ} \mathrm{C}$ temperature needed $14 \mathrm{~h} 6 \mathrm{~min}$ to hatch with a degree of abnormality of $17.3 \%$. The limits of tolerance for the incubation of the eggs of Cantik grouper (Epinephelus spp.) were $26-32^{\circ} \mathrm{C}$. The best temperature of each treatment were obtained at a temperature of $29-30{ }^{\circ} \mathrm{C}$. Based on our results, it concluded that the changing temperature affected how long eggs could hatch.
How to cite:

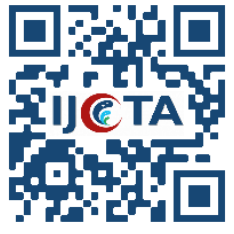

Simbolon AJ, Sutarjo GA, Hariyadi. 2019. The influence of difference temperature against the rate of embryonic development and larval cantik grouper abnormality (Epinephelus spp.). IJOTA. 2(1): 16-24.

DOI: https://dx.doi.org/10.22219/ijota.v2i1.6858

Copyright (c) 2019, Simbolon et al. This is an open access article under the CC-BY-SA license

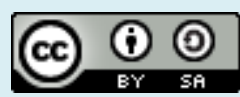

\section{Introduction}

Cantik grouper is the hybridization results grouper or cross-breeding between the Macan grouper (Epinephelus fuscoguttatus) as the parent females and grouper (Epinephelus microdon) batik as a male parent. The main barriers faced in the development of this commodity is still low 
levels of spawning up to seeding grouper (Afero et al., 2010). The main barriers faced in the development of this commodity is still low levels of spawning up to seeding grouper. Quality egg fertilization and hatching rate are high (fertility and hatching rate). One of the environmental factors that influence is huge against high fish mortality in the early phase of his life is the temperature (Pepin, 1991).

Accurate measures of egg mortality in the field involve accurate developing of the eggs, which implies a great theory of the egg developmental rates at various temperatures (Mendiola et al., 2006). Many investigations have considered the affect of temperature on the development and mortality rates of fish embryos (De March, 1995; Gillooly et al., 2002; Gracia-López et al., 2004; Yang and Chen, 2005). Based on the background, it needs to do a test of optimum temperature observations against the rate of embryonic development and Larval of cantik grouper abnormality (Epinephelus spp.).

\section{Material and methods}

\subsection{The fertilized eggs preparation}

The fertilized eggs of Cantik grouper were obtained from a commercial farm in Situbondo, East Java, and raised in Aquaculture laboratory, Aquaculture department, University of Muhammadiyah, Malang, East Java, Indonesia. The fertilized egg was put in the aquarium with supply oxygen and proper salinity.

\subsection{Research methods.}

This study used an experimental method with randomized complete design by six treatments and three replicates. The importance of temperature against the rate of larval development of Embryology and Teratology studies of Cantik Grouper (Epinephelus spp.) was examined during this study. The treatment included (A) $21-22{ }^{\circ} \mathrm{C}$; (B) $23-24{ }^{\circ} \mathrm{C}$; (C) $25-26{ }^{\circ} \mathrm{C}$; (D) $27-28{ }^{\circ} \mathrm{C}$; (E) $29--30^{\circ} \mathrm{C}$; (F) $31-32^{\circ} \mathrm{C}$. Development of Cantik Grouper larvae observed under a microscope with $40 \mathrm{X}$ magnification. The influence of temperature to normal and abnormal larvae and hatch acceleration of the larvae was examined in this study.

\subsection{Data analysis.}

All data from each treatment were evaluated statistically, employing the analysis of variance (ANOVA) based on the complete random design. The differences between the four treatment were distinguished using the Duncan test.

\section{Results and Discussion}

\subsection{Egg quality of Cantik grouper}

From the observations of egg grouper, cantik fertilized and not fertilized not knowable by consideration of the physiological characteristics of microscopically with $40 \mathrm{x}$ magnification views as follows Figure 1: 


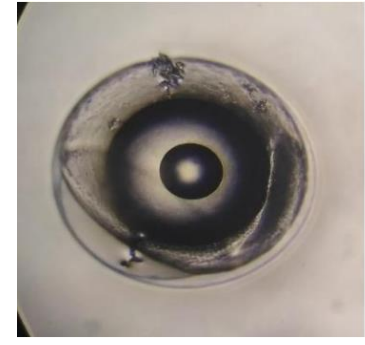

(a)

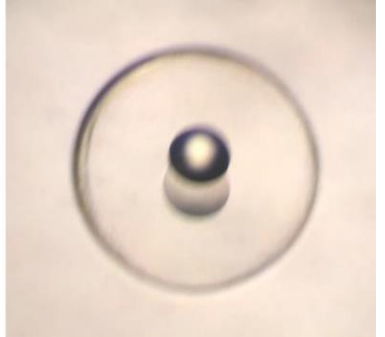

(b)

Figure 1. (a) Eggs are not fertilized, (b) Fertilized eggs

The characteristics of fish eggs that fertilized can be known by the color of the eggs are transparent, clear, uniform shape, the egg doesn't tint or colored whitish fertilized eggs not bright colored and tend to be dark. Picture 1 are in accordance with the statement of Sugama et al. (2012) fish eggs that have been fertilized can be known with its natural, transparent color or transparent, as well as eggshells or chorion free from the parasite. Fish eggs that not fertilized egg could be known with its irregular, brownish-colored or pale-colored.

\subsection{The relationship of temperature to the development of the embryo.}

The research results of observation of the embryonic development of the fertilized eggs to the development of eggs into larvae a D0 at 6 different treatment with 3 repeats. The results of the study showed that of the five different temperature treatment of temperature $21-22{ }^{\circ} \mathrm{C}$ 23-24 ${ }^{\circ} \mathrm{C}$ 25-26 ${ }^{\circ} \mathrm{C}$ 27-28 ${ }^{\circ} \mathrm{C}$ 29-30 ${ }^{\circ} \mathrm{C} 31-32{ }^{\circ} \mathrm{C}$, and obtained results which, temperature $21-22^{\circ} \mathrm{C}$ from early embryonic development fertilized eggs can develop but stalled at the blastula phase, cannot be formed until the final stage hatched. Besides, the process of embryonic development in every stage of development occurs in a long time. This is due to a too low temperature lead to the occurrence of the damage so that the enzymes that make the egg cannot hatch.

According to Melianawati et al. (2010), extreme temperatures can cause damage to the enzyme so that the work of the catalyst will be disrupted. Increasing temperature incubation can accelerate the action of the enzyme to the boundaries of optimal. When a temperature increase occurs continuously over the limit of tolerance of catalysts it will change the structure of the protein and fat enzymes can even damage the enzymes so that the egg cannot hatch instead of the lowtemperature enzyme activity will be uninterrupted even hatching enzyme cannot be secreted.

Temperature $23-24^{\circ} \mathrm{C}$ occurring phases develop embryo but at the treatment of these eggs do not develop until the eggs hatch, the pattern of development of the embryo at the treatment was stalled at the myomere phase embryos. This is because this treatment tends to be the same as the treatment at a temperature of $21-22{ }^{\circ} \mathrm{C}$ which can be described as extreme temperatures so that the egg cannot hatch.

According to Melianawati et al. (2010) States that the temperature of the media effect on hatching rate of egg hatching where the higher water temperatures the faster hatching occurs. Hatching occurs through mechanical and enzymatic work, mechanical work which caused the embryos often change its position due to the lack of space in the shell or because an embryo is longer than their surroundings in the shell. The work is an enzyme enzymatic or chemical elements called Chorion issued by glands in the endodermal embryonic pharynx. Combined mechanical and enzymatic action causing fish eggs hatch. 
The treatment temperature $25-26^{\circ} \mathrm{C}$ can be seen in the graph above long-time pattern of development of the larval embryo grouper pretty early phase occurs from heading into a stage of a D0 or hatch need continued growth over 1086 minutes or 6 hours 6 minutes. Treatment temperature $27-28{ }^{\circ} \mathrm{C}$ can be seen in the graph above long-time pattern of development of the larval embryo grouper pretty early phase occurs from heading into a stage of a D0 or hatch need continued growth over $963 \mathrm{~min}$ or $16 \mathrm{hr}$.

Treatment temperature $29-30{ }^{\circ} \mathrm{C}$ can be seen in the graph above long-time pattern of development of the larval embryo grouper pretty early phase occurs from heading into a stage of a D0 or hatch need continued growth over $900 \mathrm{~min}$ or $15.4 \mathrm{hr}$. Treatment temperature $31-32{ }^{\circ} \mathrm{C}$ can be seen in the graph above long-time pattern of development of the larval embryo grouper pretty early phase occurs from heading into a stage of a D0 or hatch need continued growth over $873 \mathrm{~min}$ or $4.6 \mathrm{hr}$.

The treatment of the five known that treatment temperature $31-32{ }^{\circ} \mathrm{C}$ produces the fastest development pattern. Temperature effect on the speed of development of the embryo, where the low-temperature development of the embryo occurs very slowly even can stop the development of the fetus. The higher the temperature the faster the growth of the embryo anyway. This is due to the ability to secrete enzymes in egg hatching thus metabolism of the embryo occurs very slowly, it can even cause the occurrence did not develop.

The process of hatching of the egg occurs affected by two things namely in the mechanical and enzymatic basis of work. Hatching eggs are mechanical work occurred resulting in embryos often change the position of the movement because of lack of space in the shell, or the size of the embryo which is longer than the shell environment. The existence of these movements the mushy parts of the eggshells will break causing the egg out of the shell. Hatching eggs are caused by the presence of enzymatic work of other chemical elements and enzymes secreted by glands endodermal. Glands in the endodermal embryonic pharynx. This enzyme is an enzyme called chorionase with a working system that is a reduction of chorion consisting of pseudokeratine become soggy. Part of the shell, which is usually broke due to the combined work of mechanical and enzymatic work, will pull out the tail part of the embryo first and then will follow his head.

Wahyuningtias (2016) stated the increase in temperature could affect the secretion of the hatching enzyme, the enzyme when hatching in secrete digestive chorion then going faster at higher temperatures than at low temperature then hatching will more quickly. On the low temperature will make the enzymes (chorion) does not work well on eggshell and create an embryo would belong in dissolving the skin so that the embryo hatches for longer. The temperature was very influential on the development of the embryo as it affects the speed of metabolism of embryos. Metabolism is a biochemical process that occurs in the body that is greatly influenced by temperature (Wawan et al., 2013).

\subsection{The relationship of temperature to speed hatch.}

The results of observation of the embryonic development of the eggs of cantik grouper (Epinephelus spp.) are observed can be seen in Table 1. The obtained results for a long time hatching eggs grouper with each treatment on $21-22{ }^{\circ} \mathrm{C}$ does not occur, the temperature on hatching $23-24^{\circ} \mathrm{C}$ in the table also doesn't happen hatching. $25-26^{\circ} \mathrm{C}$ occurs hatching where the average time it takes on this treatment during the time of $18 \mathrm{hr}, 6 \mathrm{~min} .27-28^{\circ} \mathrm{C}$ the average time is taken to hatch for $16 \mathrm{hr}$. The temperature at the treatment $29-30^{\circ} \mathrm{C}$ requires an average time 
to hatch for $15 \mathrm{hr} 1 \mathrm{~min} .31-32^{\circ} \mathrm{C}$ temperature the average time is taken to hatch for two $\mathrm{h} 6 \mathrm{~min}$. From the results above, it can be noted that the higher the temperature the faster the hatching rate. According to previous research in Melianawati et al. (2010) States that on the tiger grouper incubated at a temperature of $21-22^{\circ} \mathrm{C}$ eggs cannot hatch at a temperature of $24-25^{\circ} \mathrm{C}$, the eggs can hatch in time $21-23,27-28{ }^{\circ} \mathrm{C}$ temperature eggs hatched within $18-22{ }^{\circ} \mathrm{C}, 30-31{ }^{\circ} \mathrm{C}$ temperature eggs hatch within 16-21 hr.

Table 1. The relationship of temperature and speed of the hatch

\begin{tabular}{ccccccc}
\hline $\begin{array}{c}\text { Treatment of } \\
\text { Temperatur }{ }^{\circ} \mathrm{C}\end{array}$ & \multicolumn{3}{c}{$\begin{array}{c}\text { Hatching time } \\
\text { Repetitions (hr) }\end{array}$} & Total (hr) & $\begin{array}{c}\text { Average of hatching } \\
\text { time (hr) }\end{array}$ \\
\cline { 2 - 4 } & 1 & 2 & 3 & & 0 \\
$21-22$ & 0 & 0 & 0 & 0 & 0 \\
$23-24$ & 0 & 0 & 0 & 0 & 18.6 \\
$25-26$ & 18.7 & 18.4 & 18.7 & 54.18 & 16 \\
$27-28$ & 16 & 16.2 & 16.5 & 48.7 & 15.1 \\
$29-30$ & 15.2 & 15 & 15 & 45.2 & 14.6 \\
$31-32$ & 14.3 & 14.35 & 14.35 & 43.42 & \\
\hline
\end{tabular}

Muslim et al. (2018) states that the temperature of the media effect on hatching rate of hatching eggs incubation temperatures which affect the incubation period. Eggs in incubation at lower temperatures, the incubation takes place more significant than old eggs incubated at higher temperatures and water temperature effect on hatching eggs where the more elevated temperature then the sooner it happens hatching eggs.

\subsection{The relationship of different temperature to the degree of abnormality.}

The observations in the microscopic larvae images acquired Cantik grouper normal and abnormal as in Figure 2. If observed visually, larval Cantik grouper healthy at the time of hatching the larval body will look not bent as shown (a), whereas in the larval Cantik grouper, the abnormal new hatch will look bent tail body parts as shown in figure (b). This was confirmed by a statement from Pamenang (2017), that the larvae of abnormal grouper can be found with the body parts seem bent. Usually, this happens on the back and the tail section. Incubation temperature is very influential on against the level of normality and abnormality that can be seen in Table 2.
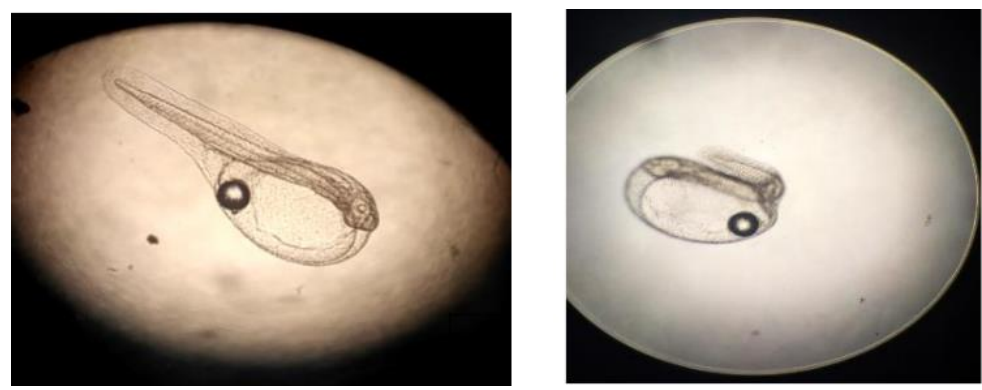

Figure 2. The healthy fish Larvae and abnormal fish Larvae

The level of normality and abnormality larvae that hatch also showed different values. The results of observations of larval Cantik grouper abnormality rate on different temperature media, where the value of the normality of the respective treatment $21-22{ }^{\circ} \mathrm{C}, 23-24^{\circ} \mathrm{C}, 25-26{ }^{\circ} \mathrm{C}, 27-$ $28{ }^{\circ} \mathrm{C}, 29-30{ }^{\circ} \mathrm{C}, 31-32{ }^{\circ} \mathrm{C}$, and a row of $0 \%, 0 \%, 13.33 \%, 34 \%, 86.33 \%, 67 \%$. As for the 
result of the value of each abnormality each treatment temperature $21-22{ }^{\circ} \mathrm{C}, 23-24{ }^{\circ} \mathrm{C}, 25-26$ ${ }^{\circ} \mathrm{C}, 27-28{ }^{\circ} \mathrm{C}, 29-30{ }^{\circ} \mathrm{C}$, and $31-32{ }^{\circ} \mathrm{C}$ respectively amounting to $0 \%, 0 \%, 8.33 \%, 7.66 \% 5.33$ $\%, 17.33 \%$. The temperature is too low to cause abnormality rates high enough and the higher the temperature the higher the level of abnormality. Seen from observations between the different temperature treatment on the development of the embryo and larval cantik grouper abnormality rate in general treatment temperature $29-30{ }^{\circ} \mathrm{C}$ yielding better value at which the pattern of development of the embryo progress is good, a low degree of abnormality and hatching is high compared to other treatments.

Table 2. The influence of temperature on the total of the normal and abnormal larvae

\begin{tabular}{|c|c|c|c|c|c|}
\hline \multirow[b]{2}{*}{ Treatment ${ }^{\circ} \mathrm{C}$} & \multirow[b]{2}{*}{$\begin{array}{c}\text { Hatching Rate } \\
(\%)\end{array}$} & \multicolumn{2}{|c|}{ Hatched Eggs (average) } & \multirow[b]{2}{*}{$\begin{array}{l}\text { Unhatched } \\
\text { (average) }\end{array}$} & \multirow[b]{2}{*}{$\begin{array}{l}\text { Total } \\
\text { Eggs }\end{array}$} \\
\hline & & $\begin{array}{l}\text { Normal } \\
\text { Larvae }\end{array}$ & $\begin{array}{l}\text { Abnormal } \\
\text { Larvae }\end{array}$ & & \\
\hline $21-22$ & 0 & 0 & 0 & 100 & 100 \\
\hline $23-24$ & 0 & 0 & 0 & 100 & 100 \\
\hline $25-26$ & 21 & 13.33 & 8.33 & 88.33 & 100 \\
\hline $27-28$ & 42 & 34 & 8 & 58 & 100 \\
\hline $29-30$ & 91.67 & 86.33 & 5.33 & 8.33 & 100 \\
\hline $31-32$ & 84.33 & 67 & 17.33 & 15.67 & 100 \\
\hline
\end{tabular}

Wawan et al. (2013) said level of abnormality larvae (larva abnormality can be seen from the morphology of larvae that are bent) low because most are still at the zone of tolerance for the activity of enzymes that play a role in embryonic development and hatching. Decreased enzyme activity resulting in reduced speed the metabolism and slows the development of the embryo. According to Melianawati et al. (2010), disorders of the body can be affected by larval incubation period, where the incubation period too long resulting in the growth of embryos in eggs is also too long and less than perfect so that the embryo does not become routine and the abnormal shape larvae will not be able to survive (Figure 3).

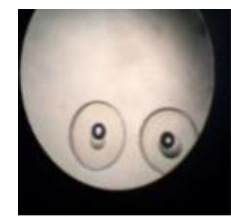

Phase 1 cell $0 \mathrm{mi}$

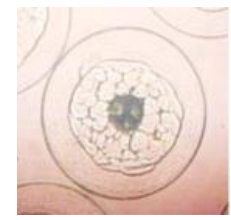

Phase 32 cell $41 \mathrm{~min}$

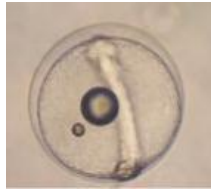

Neurula 301 min

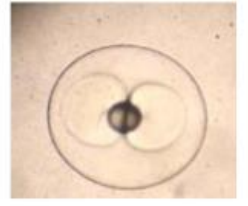

Phase 2 cell 15 min

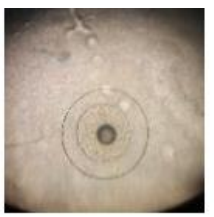

Phase 64 cell 60 min

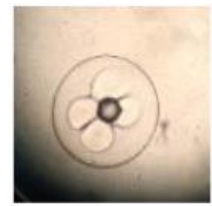

Phase 4 cell 17 min

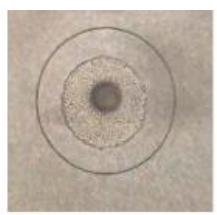

Morula 95 $\min$

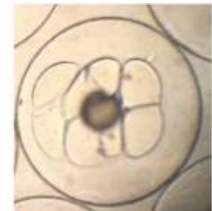

Phase 8 cell 20 minut

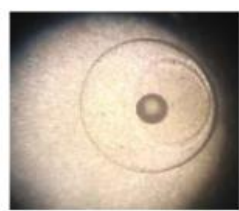

Blastula $120 \mathrm{~min}$

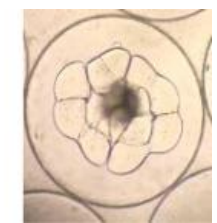

Phase 16 cell 33 minutes

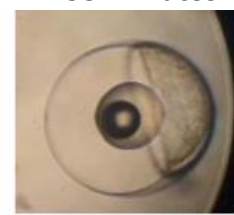

Gastrula $180 \mathrm{~min}$

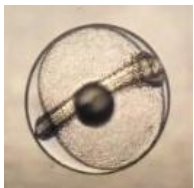

Myomere Embrio $483 \mathrm{~min}$

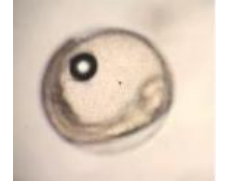

Organogenesis $672 \mathrm{~min}$

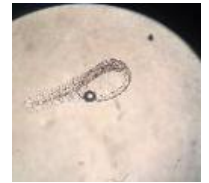

Hatch 901 min

Figure 3. Embryonic development of Cantik Grouper temperature $29-30{ }^{\circ} \mathrm{C}$ 
Results of the analysis of the significant range of visible results the value of temperature against larval grouper abnormality. This indicates that $\mathrm{HO}$ is rejected, that showed that the presence of temperature influence towards normality. To find out which temperature treatment effect then performed advanced analysis use analysis of the Duncan Multiple Range Test (DMRT).

The real difference results DMRT can be concluded that the data from the results of the calculation of the rate of larval cantik grouper abnormality at the treatment temperature $21-22{ }^{\circ} \mathrm{C}$ do not differ markedly on temperature $23-24^{\circ} \mathrm{C}$ treatment, treatment temperature $23-24{ }^{\circ} \mathrm{C}$ do not vary considerably at a temperature of $25-26^{\circ} \mathrm{C}, 27-28^{\circ} \mathrm{C}$ temperature treatment is no different with $29-30^{\circ} \mathrm{C}, 29-30^{\circ} \mathrm{C}$ treatment but vary considerably in temperature $31-32{ }^{\circ} \mathrm{C}$.

The larval body disorders grouper can be influenced by the incubation period. The longer incubation time causes abnormality of larval development. The larvae form of an abnormal body can not survive with old (Melianawati et al., 2010). The process of embryonic development from the initial phase to hatch.

\subsection{The influence of temperature against hatching rate (HR).}

Results in Table 2. of the calculation of the level of HR larval Cantik grouper at the treatment temperature $21-22{ }^{\circ} \mathrm{C}$ did not differ at temperature $23-24{ }^{\circ} \mathrm{C}$ treatment, treatment temperature 23-24 ${ }^{\circ} \mathrm{C}$ different at a temperature of $25-26^{\circ} \mathrm{C}, 27-28^{\circ} \mathrm{C}$ temperature treatment In contrast to $29-30{ }^{\circ} \mathrm{C}, 29-30^{\circ} \mathrm{C}$ treatment but differ markedly in temperature $31-32{ }^{\circ} \mathrm{C}$.

The temperature holds a critical role, which affects the process of embryo out of his shell. Temperatures are optimal over the limit causing nutrients and energy would be used more for maintenance, so the proportion of energy use for the growth development of the embryo will be decreased so that it can cause a low hatching rate (Sugama et al., 2012).

Further test results from the calculation of Duncan above can note that the temperature effect on the hatching rate (HR) in which of the six treatment temperature on the research of the treatment $29-30{ }^{\circ} \mathrm{C}$ produce the best value compared to other treatments. Treatment temperature on the development of the embryo and Larval grouper abnormality can be grown from $25-32{ }^{\circ} \mathrm{C}$ but the most optimum for the development in the development of the embryo and larval abnormality rates low and the value of HR wrote best at a temperature of $29-30^{\circ} \mathrm{C}$.

\subsection{Water Quality.}

Water quality is the most essential factor endowments in a cultivation activities, including grouper. Inadequate water quality health affects fish that can be kept. According to Bobe (2015), water quality is closely related to factor stress fish due to changes in water quality parameters. Water quality parameters measured in this study include temperature, $\mathrm{pH}$, salinity and $\mathrm{DO}$. These parameters will affect the metabolic processes of the body such as grouper liveliness foraging, digestion, and growth of grouper. Water quality measurement data is presented in Table 3.

DO or dissolved oxygen according to Boyd and Tucker (2012), is a limiting factor, so if its availability in the waters of the insufficient existing organism needs, then all activity of the organism will be disturbed. The content of dissolved oxygen in waters at least is ppm. Dissolved oxygen in the study measured using DO meters. The results indicate that the incubation media DO the eggs until they hatch of 4.7-6.4 ppm. These values are still appropriate for the maintenance of the 
grouper. To maintain water quality mainly dissolved oxygen in this study then the use of the aerator as a source of dissolved oxygen.

Table 3. Measurements of water quality during the study

\begin{tabular}{ccccc}
\hline Perlakuan & Suhu $\left({ }^{\circ} \mathrm{C}\right)$ & DO $(\mathrm{ppm})$ & $\mathrm{pH}$ & Salinitas (ppt) \\
\hline $21-22{ }^{\circ} \mathrm{C} \mathrm{P1}$ & $21-22$ & 5 & 8 & 33 \\
$23-24{ }^{\circ} \mathrm{C} \mathrm{P2}$ & $23-24$ & 5 & 8 & 33 \\
$25-26^{\circ} \mathrm{C} \mathrm{P3}$ & $25-26$ & 5 & 8 & 33 \\
$27-28{ }^{\circ} \mathrm{C} \mathrm{P4}$ & $27-28$ & 5 & 8 & 33 \\
$29-30{ }^{\circ} \mathrm{C} \mathrm{P5}$ & $29-30$ & 5 & 8 & 33 \\
$31-32{ }^{\circ} \mathrm{C} \mathrm{P6}$ & $31-32$ & 5 & 8 & 33 \\
\hline
\end{tabular}

The degree of acidity $(\mathrm{pH})$, namely the level of acidity of water stated in the $\mathrm{pH}$ of the water. $\mathrm{pH}$ for activity research shows constant results, namely the range of 8 . This is in accordance with statement of Kordi (2007), that the magnitude of the $\mathrm{pH}$ of the water is optimal for the life of the grouper is 7.5-8.5 because at that range indicates the optimal balance between oxygen and carbon dioxide, as well as a variety of microorganisms the harm will be difficult due to the growing conditions of the waters acidic or very alkaline, will jeopardize the survival of the organism because it will cause the onset of disorders of metabolism and respiration.

According to Adriani (2004) salinity is the salt levels throughout a substance dissolved in 1000 $\mathrm{g}$ of water. Salinity also has an important role in the life of aquatic organisms, either fish or shrimp, which physiologically salinity is closely related to the adjustment of the aquatic animal's osmotic pressure. Salinity during the activities of the research indicates a steady result i.e. 33 ppt. It can be reinforced with revelatory Kordi (2007) that the optimal salinity range for hatching grouper is 3334 ppt.

\section{Conclusion.}

Temperature effect on embryonic development and larval cantik grouper abnormality that occurs where the temperature effect on embryonic development in which $21-22{ }^{\circ} \mathrm{C}$ phase of development of the embryo develops from the initial stage to the blastula only $23-24{ }^{\circ} \mathrm{C}$ early phase of embryonic development, dare only lasted until phase myomere embryo and hatching does not occur. $25-26{ }^{\circ} \mathrm{C}$ phase of development took place from the fasea start to hatch with a long time for $18 \mathrm{~h} 6 \mathrm{~min}$ by $8.33 \%$ abnormality rate. $27-28{ }^{\circ} \mathrm{C}$ stage of development took place from the start face to hatch with a long time for 16 hours with a rate of $7.6 \%$ abnormality. $29-30{ }^{\circ} \mathrm{C}$ phase of development took place from the initial stage to hatch with a long time for 15 hours 1 min levels of abnormality of $5.33 \% .31-32{ }^{\circ} \mathrm{C}$ stage of development took place from the fasea start to hatch with a long time for $14 \mathrm{~h} 6 \mathrm{~min}$ with a degree of abnormality of $17.3 \%$. Optimum temperature against the pace of development of the embryo and the cantik grouper abnormality that is at a temperature of $29-30{ }^{\circ} \mathrm{C}$.

\section{References}

Afero F, Miao S, Perez AA. 2010. Economic analysis of tiger grouper Epinephelus fuscoguttatus and humpback grouper Cromileptes altivelis commercial cage culture in Indonesia. Aquaculture international. 18: 725-739. 
Andriani S. 2004. Management of water quality for aquaculture. University of Brawijaya Malang. Bobe J. 2015. Egg quality in fish: Present and future challenges. Animal Frontiers. 5: 6672-6690.

Boyd CE, Tucker CS. 2012. Pond aquaculture water quality management, Springer Science \& Business Media.

De March B. 1995. Effects of incubation temperature on the hatching success of Arctic char eggs. The Progressive Fish-Culturist. 57: 132-136.

Gillooly JF, Charnov EL, West GB, Savage VM, Brown JH. 2002. Effects of size and temperature on developmental time. Nature. 417: 70.

Gracia-López V, Kiewek-Martínez M, Maldonado-García M. 2004. Effects of temperature and salinity on artificially reproduced eggs and larvae of the leopard grouper Mycteroperca rosacea. Aquaculture. 237: 485-498.

Kordi MGH, Tanjung AB. 2007. Management of water quality in aquaculture. Jakarta: Cipta Rineka.

Mendiola D, Alvarez P, Cotano U, Etxebeste E, de Murguia AM. 2006. Effects of temperature on development and mortality of Atlantic mackerel fish eggs. Fisheries Research. 80: 158-168.

Melianawati R, Imanto PT, Suastika M. 2010. Planning on hatching time of grouper eggs through different incubation temperatures. Jurnal Ilmu dan Teknologi Kelautan Tropis. 2.

Muslim M, Fitrani M, Afrianto AM. 2018. The effect of water temperature on incubation period, hatching rate, normalities of the larvae and survival rate of Snakehead fish Channa striata. Aquacultura Indonesiana. 19: 90-94.

Pamenang GD. 2017. Teknik pembesaran ikan kerapu cantik (Epinephelus spp.) pada keramba jaring apung di unit pelaksana teknis pengembangan budidaya laut (UPT PBL) Situbondo.

Pepin P. 1991. Effect of temperature and size on development, mortality, and survival rates of the pelagic early life history stages of marine fish. Canadian Journal of Fisheries and Aquatic Sciences. 48: 503-518.

Sugama K, Rimmer M, Ismi S, Koesharyani I, Suwirya K, Giri N, Alava V. 2012. Hatchery management of tiger grouper (Epinephelus fuscoguttatus): a best-practice manual, Australian Centre for International Agricultural Research (ACIAR).

Wahyuningtias I. 2016. Pengaruh suhu terhadap perkembangan telur dan larva ikan tambakan (Helostoma temminckii).

Wawan A, Bejo S, Ariawan IMDJ. 2013. Embryonic development and hatching eggs ratio of Blacksaddled Coral Grouper (Plectropoma laevis) at different temperature media. Jurnal IImu dan Teknologi Kelautan Tropis. 5.

Yang Z, Chen Y. 2005. Effect of temperature on incubation period and hatching success of obscure puffer Takifugu obscurus (Abe) eggs. Aquaculture. 246: 173-179. 